\section{Modeling Italian forests: state of the art and future challenges}

\author{
Giorgio Vacchiano $^{(1)}$, Federico Magnani ${ }^{(2)}$, Alessio Collalti ${ }^{(3)}$
}

This review is a follow-up to the first meeting of the Forest modeling working group (FMWG) of the Italian Society of Silviculture and Forest Ecology (SISEF), held in December 2009. 18 talks were delivered to an audience of 40 researchers. We review the state of the art of forest ecosystem modeling in Italy, highlight findings from Italian research groups, and summarize relevant issues. Developing on the discussion session of the meeting, we indicate current research gaps and future challenges for modelers, forest ecologists and foresters alike, with a special emphasis on model validation, data availability, and communication between researchers and managers.

Keywords: Forest Models, Forest Inventory, SISEF, Ecological Modeling, Carbon Balance

\section{Introduction}

Simulation models of forest ecosystems answer two needs: clarifying the relationship between key ecosystem components, for a deeper understanding of their functioning (Kimmins 2008), and predicting how the state variables of a dynamic system change due to processes in a forest stand or landscape (Brang et al. 2002). The comparison with desired targets will then result in improved ecosystem management. Modeling tools are increasingly used by both forest ecologists, who face the challenge of transferring knowledge to stakeholders and the general community, and managers, who benefit from the development of scenario-based supports for decision-making.

(1) Department of Agriculture, Silviculture and Land Management, Università di Torino, v. L. da Vinci 44, I-10095 Grugliasco (TO Italy); (2) Department of Fruit Tree and Woody Plant Science, Università di Bologna, v.le Fanin 46, I-40127 Bologna (Italy); (3) Impacts on Agriculture, Forest and Natural Ecosystem division (IAFENT), Centro EuroMediterraneo per i Cambiamenti Climatici, v. Augusto Imperatore 16, I-73100 Lecce (Italy)

@, Giorgio Vacchiano

(giorgio.vacchiano@unito.it)

Received: Mar 14, 2012 - Accepted: Apr 10, 2012

Citation: Vacchiano G, Magnani F, Collalti A, 2012. Modeling Italian forests: state of the art and future challenges. iForest 5 : 113-120 [online 2012-06-05] URL: http://www.sisef.it/iforest/contents? id=ifor $0614-005$
Several definitions of models exist. From a general point of view, modeling means trying to capture the essence of a system, deconstructing complex interactions between system components until only the most essential structures and processes remain (Haefner 2005). This refers to a descriptive level of ecological science. However, when management of natural resources is at stake, the value of ecological models lies in principle in their predictive power. Process-based and empirical models make it possible to predict the present value of a variable of interest (biomass, $\mathrm{C}$ sequestration, biodiversity, stem growth, etc.) from simultaneous values of other driving variables (climate, soil, stand density, etc.). By assuming that processes hold across time (Pickett \& Kolasa 1989), ecologists use models developed and validated for current conditions to make predictions of future system trajectories. In this perspective, we define models as quantitative tools that predict the future probability distribution of an ecological variable, conditional upon initial conditions, parameter distributions, distributions of extrinsic drivers, and the choice of mathematical or statistical penter 2002). Simulators, on the other hand, refer to computer programs resulting from the conversion of such models into a piece of software for scenario calculation, and often visualization (Pretzsch et al. 2006).

The state-of-the-art in forest ecosystem modeling has been presented in several conferences (e.g., Fries 1974, Ek et al. 1988, Burkhart et al. 1989, Dixon et al. 1990, Wensel \& Biging 1990, Amaro \& Tomé 1999, Rennols 2001, LeMay \& Marshall 2003, Hasenauer \& Mäkelä 2005), and much of the accumulated knowledge is summarized by textbooks (Dudek \& Ek 1980, Dixmethods used to make the calculations (Car- on et al. 1990, Solomon \& Shugart 1993 Vanclay 1994, Mladenoff \& Baker 1999, Von Gadow \& Hui 2001, Thornley \& Johnson 2002, Amaro et al. 2003, Grimm \& Railsback 2005, Hasenauer \& Mäkelä 2005, Hasenauer 2006, Pretzsch et al. 2006, Voinov et al. 2008, Pretzsch 2009). The diversity in ecosystem processes has resulted in the development of an extraordinary array of different models in forest ecology and management. Several and sometimes conflicting classification schemes have been proposed for models, based on their descriptive or explanatory purpose (represented by empirical and process models, respectively), ecosystem component addressed, spatial resolution and context, temporal extent, deterministic or stochastic nature (Munro 1974, Shugart et al. 1988, Bossel 1991, Vanclay 1994, Pretzsch 1999, Franc et al. 2000, Peng 2000, Porté \& Bartelink 2002, Monserud 2003, Pretzsch et al. 2008, Taylor et al. 2009). Pretzsch et al. (2008) gave an overview of modeling approaches in Europe. The University of Kasselm, Germany maintains an internet-based Register of Ecological Models (Benz \& Knorrenschild 1997

http://ecobas.org/www-server/index.html) with references to 681 models (as of March 2011); the Forest Model Archive is another such repository of forest models, maintained by the University of Greenwich, UK (Rennolls et al. 2001). Other databases include ForMIS, a database of European yield tables and empirical tree-scale models that includes model equation and parameters (Sims 2009), and the more recent FORMODEL hosted by the Institute Européen de la Foret Cultivée (Orazio 2009). The latter is able to receive user input on newly developed models. The increasing interest in forest ecosystem modeling in Europe is reflected by the recent activation of two EU-COST ${ }^{1}$ projects: FP0603 - "Forest models for research and decision support in sustainable forest management" (http://www.isa.utl.pt/def/fp0603 forestmodels), aiming to enhance the quality and consistency of forest growth models to simulate the responses of forests to alternative management and climate scenarios (Bugmann et al. 2010); and FP0804 - "Forest Management Decision Support Systems (FORSYS)" (http://fp0804.emu.ee), that will define a European-wide framework and requirements for forest decision support systems (DSS) in a sustainable multifunctional forest management environment. FP0603 called for the identification and description of forest growth models available in Europe. Fifteen out of 23 nations have provided a country report (Palahí 2008), Italy not being among them.

The first meeting of the Working group for Forest ecosystem modeling of the Italian Society for Silviculture and Forest Ecology 
Tab. 1 - Facts and figures of the Italian forest system.

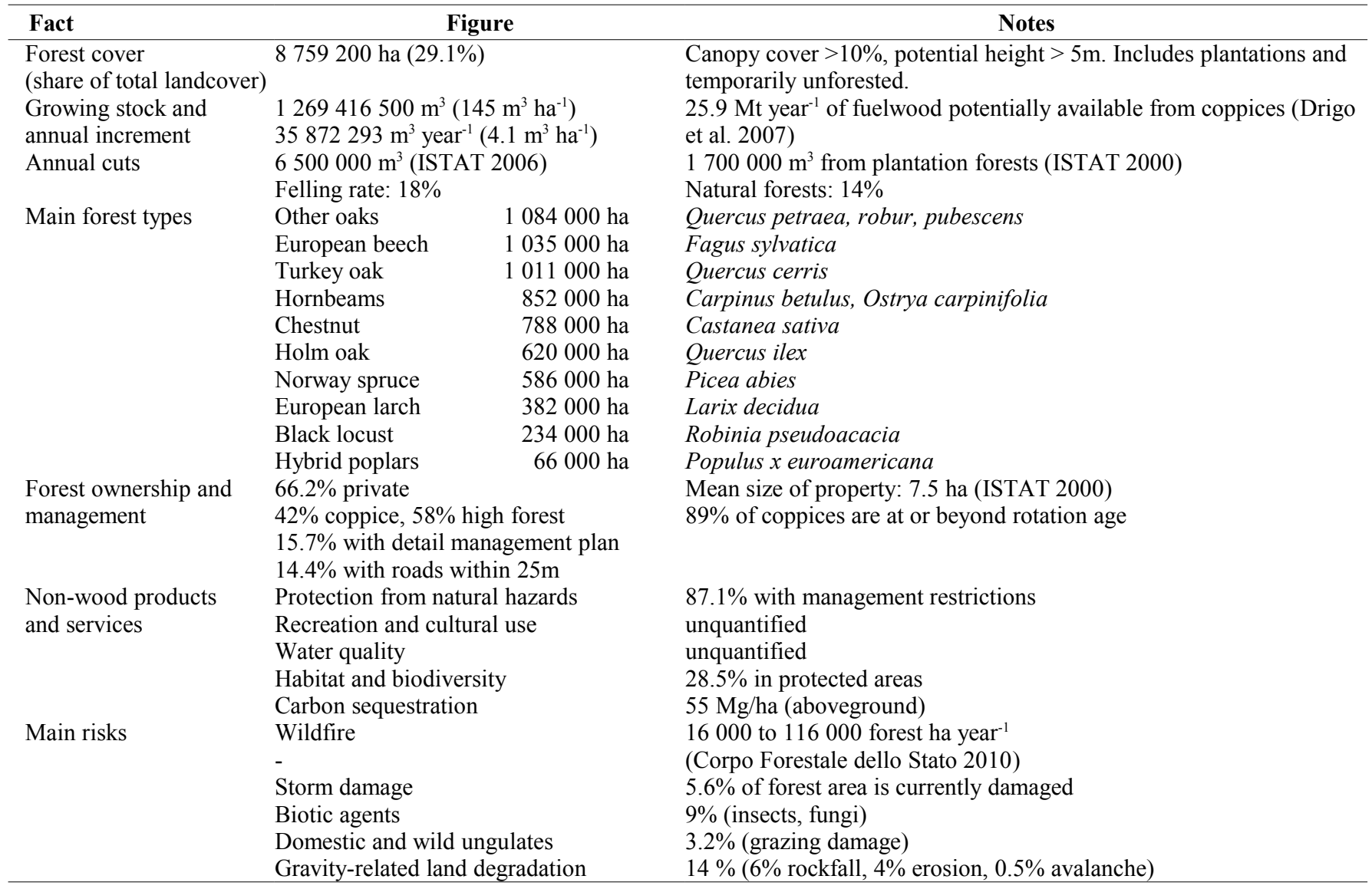

(SISEF), held in Bologna on $18^{\text {th }}$ December, 2009, provided a comprehensive overview of the current efforts in simulating and forecasting forest ecosystem processes in Italy. Some 18 talks $^{2}$ were delivered to an audience of about 40 researchers. In this paper we review the state of the art of forest ecosystem modeling in Italy, highlighting findings from Italian research groups. Following up on the concluding remarks from the meeting, we summarize relevant issues, research gaps and future challenges, with an emphasis on data availability, calibration and validation methods, model choice and communication between researchers and managers.

\section{Modeling forest ecosystems: country report}

To set the scene, we find it useful to summarize key figures of Italian forests (Tab. 1), as assessed by the National Forest and Carbon Inventory (INFC 2005) unless otherwise stated, in order to provide reference values for readers unfamiliar with the country and to harmonize this account to country reports produced by other members of COST FP0603.

The figures reported in Tab. 1 reflect the average or summary state of Italian forests, but variability is extremely high within the country. Differences in elevation (0 to 4810 $\mathrm{m}$ a.s.1.), climate regime (mediterranean to oceanic or continental), past and current land use, social and economic factors between regions or even adjacent valleys, give origin to a fine-grained mosaic of sites, stand structures and forest cover types. Such a diverse pattern might be one of the reasons for the lack (until recently) of a forest modeling tradition. We will report the state of the art of forest modeling in Italy following the classification scheme proposed by Pretzsch et al. (2008).

\section{Empirical models}

Statistical stand models such as yield tables have been developed over the past fifty years for the most productive forests of the country (e.g., Bernetti et al. 1969, Bianchi 1981, Castellani 1982, Amorini et al. 1998, Cantiani et al. 2000, Ciancio \& Nocentini 2004) but, like all empirical models, are hardly applicable in sites other than those they were calibrated for and they do not take into account climate changes. Moreover, some of such tables are now outdated, because they do not reflect the changes occurred since theiy were developed in site conditions or management operations. Empirical standscale models may still be useful as decision support systems (DSS) aimed at simulating the average development of stand structure and the provision of related forest services over well-defined areas and short to medium timespans. For example, Vacchiano et al. (2008) developed a stand density management diagram for Scots pine (Pinus sylvestris L.) forests with a direct protective role against rockfall.

Size distribution models, on the other hand, have never obtained much practical relevance in Italy. As a notable exception, Markovian models of the transition probability between diameter classes (Bruner \& Moser 1973) have been suggested for mixed, uneven-aged forests of the eastern Alps (Virgilietti \& Buongiorno 1997, Gasparini et al. 2000).

Individual tree models explicitly simulate the development of single trees considering their interactions within a spatial-temporal system, and account for feedback loops between stand structure and individual growth. This enables them to simulate pure and mixed stands of all age structures and intermingling patterns equally well. Standlevel data for forestry management are finally provided by aggregation of the single tree results (Pretzsch et al. 2008). Individualtree empirical models have previously been 
designed for alpine Beech (Fagus sylvatica L.) forests (Cescatti \& Piutti 1998), Douglas fir and hybrid poplar plantations (Scotti et al 1995, Corona et al. 1997, 2002) and are currently being developed to forecast yield in plantations for quality timber such as common walnut (Juglans regia L. - D. Cimini, personal communication). Morani (2009) showed the potential of UFORE, an individual-tree growth model for predicting the dynamics and air-quality benefits of planted trees in an urban context.

Depending on the modeling purpose, several individual growth and yield simulators might be available from the international literature, e.g., CAPSIS (Dreyfus \& Bonne 1996), MOSES (Hasenauer 1994), SILVA (Pretzsch \& Kahn 1996) and the Forest Vegetation Simulator (FVS - Dixon 2003, based on early work by Stage 1973). Issues of accuracy and scale have been associated to the use of empirical growth and yield models in Europe (Corona \& Scotti 1998). Those who intend to adopt them face two major challenges: (1) the availability of repeated forest inventories for the focus landscape that provide the input and output variables needed for calibrating empirical growth equations; (2) the inclusion of the impact of climate and site changes on future productivity (Fontes et al. 2010). To accomplish the latter, model developers must link their input to external, process-based or bioclimatic envelope models, as discussed in his invited talk at the FMWG meeting by Nicholas Crookston from the US Forest Service (Crookston et al. 2010).

\section{Gap, hybrid and landscape models}

Gap models (Bugmann 2001) and, on a larger scale, landscape dynamics models ( $\mathrm{He}$ 2008), explicitly include site and climate drivers for predicting forest composition, structure and biomass.

Small-area or gap models reproduce the growth of single trees in forest patches (e.g. $100 \mathrm{~m}^{2}$ ) in relation to the prevailing growth conditions at the site (Botkin et al. 1972, Shugart 1984, Leemans \& Prentice 1989). However, physiological processes are not explicitly accounted for, requiring statistical fitting procedures between each environmental factor and observed growth. The combination of knowledge on specific ecophysiological process with stand or single tree management models and with long-term growth measurements results in the so-called hybrid growth models (Kimmins 1993). In Italy, no developments of either gap or hybrid models have been proposed to date; SORTIE-ND (Pacala et al. 1993) might represent a suitable simulator for future adaptations.

Landscape models comprise a broad class of spatially explicit models that incorporate heterogeneity in site conditions, neighborhood interactions and feedbacks between different spatial processes (Pretzsch et al. 2008). The role of these models is to develop scenarios for the sustainability of forest or landscape functions (natural resources, habitat, hydrology, socioeconomic), to forecast their response to disturbances and potential environmental change (climate, $\mathrm{N}$ deposition, land use), to analyze the relationship between landscape structure and regionally distributed risks, and to assess regional-scale matter fluxes, e.g., water, carbon and nutrients. One example is the mesoscale SILVA Land Surface Model (Alessandri \& Navarra 2008) that represents the momentum, heat and water flux at the interface between land-surface and atmosphere, and has been coupled to a general circulation model (GCM) to estimate the rate of forcing by existing vegetation on precipitation patterns. At a different scale, other examples of spatially explicit landscape modeling presented at the FMWG meeting are calibrated of fire spread and behavior simulators to a Mediterranean ecosystem by Arca et al. (2007) and eco-hydrological models currently used to forecast water (runoff, snowmelt, evapotranspiration, uptake) and energy (heat, radiation) budgets at the plot and catchment scale (Marletto et al. 1993, Rigon et al. 2006, Bittelli et al. 2010).

Landscape models should be distinguished from models based on spatial data layers at the landscape or regional scale, but without the explicit representation of neighborhood interactions. These should be rather viewed as local models embedded into geographic information systems (GIS). Output variables are predicted based on their relationship with topographic, climatic, biometric or ecophysiological information, either ground-based or remotely-sensed. The link between input and output variables is often based on empirical relationships or multivariate and multicriteria analysis. Examples were given in the fields of fire risk prediction (e.g., Ventura et al. 2001, Laneve \& Cadau 2007, Camia 2009), habitat suitability (Boitani et al. 2002, Fiorese et al. 2005, Brugnoli \& Brugnoli 2006), and plant species distribution in response to climate change scenarios (Attorre et al. 2008).

Alternatively, GIS-based models can incorporate detailed information on ecophysiological processes, as for the development of the 3PG-s model presented by Nolé at the FMWG meeting (Coops et al. 1998, Nolé et al. 2009).

\section{Matter-balance models}

Most of the simulators presented at the FMWG meeting were focused on process based models (PBMs) and widely described in literature. Simulated processes involve primary productivity (3-PG - Landsberg \&
Waring 1997; FOREST-BGC - Waring \& Running 1998), nitrogen (3-PGN - Xenakis et al. 2008), and carbon fluxes (C-FIX - Veroustraete et al. 2002), including estimation of C sequestration (NASA-CASA - Potter et al. 1998), heterotrophic (Nolé et al. 2009) and autotrophic respiration (Minunno et al. 2010). Models in the process-based family that are closest to the operational application stage can simulate growth and yield of a single stand (Makela et al. 2010). However, there are also models being developed to address larger, regional and successional scale problems, e.g., GIS-based models of stand development in the tropics (Ditzer et al. 2000). Process-based modeling can be defined as a procedure by which the behavior of a system is derived from a set of functional components and their interactions with each other and the system environment, through physical and mechanistic processes occurring over time (Godfrey 1983, Bossel 1994). Matter balance, or process-based, models focus on the description of water and nutrient ( $\mathrm{C}$ and $\mathrm{N}$ ) balance, based on biogeochemical processes. They consider vegetation development primarily as a change of matter in different compartments based on uptake (e.g., photosynthesis) and loss (e.g., mortality and biomass turnover) processes that in turn depend on environmental conditions (Pretzsch et al. 2008). Many of these models use the well-known light use efficiency approach (or radiation use efficiency), which estimates the conversion efficiency of $a b$ sorbed photosynthetically active radiation (APAR) into gross primary production (GPP). The tenet is that GPP is a linear function of APAR reduced by environmental constraints on Light Use Efficiency (McMurtrie et al. 1994, Landsberg \& Waring 1997, Running et al. 2004) and integrating the ecophysiological processes related to the carbon and water balance. A large validation effort has been made in recent years for these type of models, often using satellite data to develop spatially-explicit model versions, with a high simplification in the Leaf Area Index or fraction of absorbed PAR computation (i.e., 3-PGs - Nightingale et al. 2008; CFIX - Veroustraete et al. 2002).

Many process based models were developed for even-aged, monospecific stands (plantations), a fact that may reduce their usability in forests with highly complex structure. Efforts are underway by the authors to adapt simple models developed for tropical rainforests into more complex models, able to consider the presence of more than one cohort or species or integrating light competition within layered models (Collalti et al. 2010).

\section{Emerging themes and challenges}

The FMWG meeting showed that the currently prevailing interest in the Italian forest 
modeling community is for the process-based modeling of forest ecosystem productivity, based on knowledge of physiological and ecosystem processes. This may be due to several reasons: the complexity of fores landscapes, the shift from a timber-oriented to an ecosystem- or even carbon-oriented management paradigm, the lack of homogenized inventory data for calibration of empirical models, or else the recently established body of research and data on carbon cycling and sequestration in European forest ecosystems, e.g., measurements from the Fluxnet and CarboEurope networks (Baldocchi et al 2001, Valentini 2003).

Process models have clear advantages over empirical models, allowing researchers to answer some of the most pressing questions in current plant ecological science, such as the amount of carbon fixed by a given community or landscape, or the response of tree performance to climatic fluctuations or atmospheric $\mathrm{N}$ depositions (e.g., Eastaugh et al. 2011). Provided that appropriate data be available as input variables (see below), we suggest directing research towards understanding ecosystem response to exogenous disturbances. Applications of process models have been run so far in controlled environments, i.e., forests or landscapes driven only by endogenous dynamics, with different climate input parameters. Since climate change is likely to affect disturbance regimes (Dale et al. 2001), which in turn have a strong impact on forest productivity, the study of tree and stand response to disturbances of different kinds and intensities is a desirable integration to the current modeling framework Natural disturbance patches and events, from both abiotic and biotic agents, can serve as case studies to retrospectively test existing individual tree and stand-scale models Moreover, specific simulators have been developed to model disturbance-related risk and impact in forest ecosystems, and could be useful for both management and ecological research (Hanewinkel et al. 2010, Seidl et al. 2011).

A further example of an underdeveloped research area is represented by forest-wildlife interactions, with specific reference to ungulate browsing on regeneration. Satisfactory models (empirical or GIS-based) already exist to define habitats suitable to animal species of interest. However, both processbased and growth and yield models usually lack a reliable regeneration algorithm (Price et al. 2001); including the selective impact of mammal (or even insect) herbivory is a necessary step towards the simulation of actual ecosystem dynamics, especially for mountain forests (Weisberg et al. 2005).

In order to be both usable and useful for managers, models must be kept as simple as possible; adding sub-components without increasing prediction error and/or decrease usability is a difficult task. Nevertheless, two features emerged at the FMWG meeting that should be considered for general integration within existing simulators: (1) soil-related processes and (2) spatial referencing of model output. The role of soil organic matter in forest carbon budget appears at the same time very influential (Liski et al. 2002) and poorly understood, principally because of lacking field data. Models addressing soil-related dynamics or incorporating soil subcomponents have been developed (BIOMEBGC, G-DAY, Century; see e.g. Scarfò \& Mercurio 2009, Zaehle \& Dalmonech 2011). More data and research are needed to improve their predictions, linking soil carbon budget to deadwood dynamics and root assimilation, and finally estimating belowground $\mathrm{C}$ pools for integration into aboveground simulations.

The second feature, i.e., making model outputs attributable to spatial units in the landscape, was briefly explored during the meeting, but only at the scale of nation- or region-wide simulations of carbon stocks (Maselli et al. 2009) or statistical climate-species response profiles (Attorre et al. 2008). Following the example of hydrological models, which by definition work on landscape cells in catchments, simulators of stand composition, biomass and productivity should predict the spatial variability of such attributes across a forested landscape. Not only managers would benefit from a landscape-explicit approach, but research about landscape connectivity, fragmentation, energy flows and functional relationships between ecosystem components would be made possible. An example of such an approach are the simulators LANDIS-II (Scheller et al. 2007), that links process-based estimates of forest composition and growth to landscape pixels of variable size (typically 10 to 500 meters), and iLand (Seidl et al. 2012), that adopts a hierarchical multi-scale modeling framework scaling up from individual trees to the landscape.

At any rate, models should be tailored towards the final users, be they researchers or land managers. Empirical models, where adequately calibrated, may be the best option to pursue when forest composition, yield and structure need to be described at the stand scale and for limited temporal spans. Empirical relationships or functions are often used when modeling emergent properties such as self-thinning and mortality dynamics, that have not been predicted to date by physiological processes at the individual tree level. Research on hybrid models, capable of transferring specific eco-physiological process knowledge to stand or single tree management models that are evaluated against longterm growth measurements, has been indicated as a priority for forest ecology throughout (Kimmins 1993, 2008).

\section{Further challenges for modelers}

A number of the issues emerged from the panel discussion of the FMWG meeting directly concerning the modelers' community, rather than the ecological or silvicultural applications of the models. Here we briefly summarize the major points of concern:

- Data availability. Data for calibration and validation of models at all scales are not sufficiently available, due to a lack of long-term ecological studies, poor harmonization of available datasets, and poor dissemination of existing data sources (including the National Forest Inventory INFC, see Borghetti \& Ferrara 2010). We recommend that bottlenecks in data collection and analysis be avoided as strongly as possible, and advocate for open release of raw data from the INFC following the example of some European countries (such as France or Spain) and the United States. We also think that a stronger interaction between modelers and other research communities, including field surveyors, would improve and homogenize data collection standards across studies and sites.

- Model documentation and availability. While open-sourcing a simulator remains a developer's choice, each piece of software or equation should be accompanied by adequate metadata and documentation, in order to respect science's transparency and repeatability canons. While metadata would improve adaptation of existing models to new species or sites, newly developed models should be registered together with their relevant documentation on existing online archives (see Introduction). Metadata templates could also be introduced in data collection routines (Michener 2006).

- Calibration and validation. Validation of model output against independent data is a too-often missing component when reporting results of model-related research. We advise recurring to multiple data sources for evaluation of model output, e.g., by integrating field-based and remotely-sensed data, or by assessing the ecological realism of ecosystem behavior as predicted by a simulator (model "evaluation" sensu Vanclay \& Skovsgaard 1997). Recently developed tools for model calibration, validation and performance comparison could be of more general use, including Bayesian calibration (Van Oijen et al. 2005), resampling methods (Marziliano 2009), and the use of information theory (Arnold 2010).

- Issues of scale. Modelers should have an understanding of all the process represented in their simulators. They ought to recommend the most appropriate spatio-temporal scale of simulation and application of the results, in order to avoid undesired propagation of model error due to lar- 
ger-than-appropriate temporal or spatial extents. Upscaling or downscaling model predictions is often carried out too lightly, as it would require an understanding of functional relationships between scales (both grain and extent, sensu Wiens 1989) and a hierarchical approach to ecosystem modeling (O'Neill et al. 1986, Robinson \& Ek 2000). A successful attempt to scale up from stand to continental scale was recently developed by Franklin et al. (2012).

\section{Conclusion}

As a conclusive remark, we would like to make a case for communication. Scientists involved in ecological research should make all efforts for an effective communication of their results, especially when they can be applied for a better management of natural resources. Even when not solicited by explicit demand, model developers should make all efforts to transfer information enclosed by model output to all stakeholders and to the general public (or even the press). Contributors to COST project FP0603 are developing guidelines for forest sustainability indicators to be included as model outputs following Pan-European criteria and indicators for ecological, economic and social sustainability (MCPFE 2000). However, the choice of model output variables should be tailored on prospective users, a process that could be made very effective by preliminary interaction between the two categories of subjects, in order to avoid "ivory tower" behaviors. Participation of stakeholders to forest planning is a promising field and has already been successfully implemented in some cases. Communicating with end-users, spreading "user friendly" releases of simulator software, equipping models with realistic visualization tools, and providing continuing education and training, will deserve great attention and effort if forest simulators are desired to serve as real decision support tools, and not mere computational exercises.

\section{References}

Alessandri A, Navarra A (2008). On the coupling between vegetation and rainfall inter-annual anomalies: possible contributions to seasonal rainfall predictability over land areas. Geophys. Res. Lett. 35: L02718. - doi: 10.1029/2007GL032415 Amaro A, Reed D, Soares P (2003). Modelling forest systems. CABI, Oxford, UK. - doi: 10.1079/9780851996936.0000

Amaro A, Tomé M (1999). Empirical and process based models for forest tree and stand growth simulation. In: Proceedings of a IUFRO Conference. Oeiras (Portugal), 21-27 September 1997. Edicões Salamandra, Lisboa, Portugal.

Amorini E, Brandini PG, Fabbio G, Tabacchi G (1998). Modelli di previsione delle masse legnose e delle biomasse per i cedui di cerro della Toscana centro-meridionale. Annali dell'istituto Sperimentale per la Selvicoltura 29:
41-56.

Arca B, Duce P, Laconi M, Pellizzaro G, Salis M, Spano D (2007). Evaluation of FARSITE simulator in mediterranean maquis. International Journal of Wildland Fire 16: 563-572. - doi: 10.1071/WF06070

Arnold TW (2010). Uninformative parameters and model selection using Akaike's information criterion. Journal of Wildlife Management 74 (6): 1175-1178. - doi: 10.1111/j.1937-2817.2010. tb01236.x

Attorre F, Francesconi F, Scarnati L, De Sanctis M, Alfò M, Bruno F (2008). Predicting the effect of climate change on tree species abundance and distribution at a regional scale. iForest 1: 132139. - doi: 10.3832/ifor0467-0010132

Baldocchi D, Falge E, Gu LH, Olson R, Hollinger D, Running S, Anthoni P, Bernhofer C, Davis K, Evans R, Fuentes J, Goldstein A, Katul G, Law B, Lee XH, Malhi Y, Meyers T, Munger W, Oechel W, U KTP, Pilegaard K, Schmid HP, Valentini R, Verma S, Vesala $T$, Wilson $K$, Wofsy S (2001). Fluxnet: a new tool to study the temporal and spatial variability of ecosystem-scale carbon dioxide, water vapor, and energy flux densities. Bulletin of the American Meteorological Society 82: 2415-2434. - doi: 10.1175/1520-0477(2001)082<2415:FANTTS $>$ 2.3. $\mathrm{CO} ; 2$

Benz J, Knorrenschild M (1997). Call for a common model documentation etiquette. Ecological modelling 97: 141-143. - doi: 10.1016/S03043800(96)00055-5

Bernetti G, Cantiani M, Hellrigl B (1969). Ricerche alsometriche e dendrometriche sulle pinete di pino nero e laricio della Toscana. L'Italia Forestale e Montana 44 (1): 10-33.

Bianchi M (1981). Le fustaie di faggio di origine agamica della Toscana: tavole di produzione per i boschi coetanei. Annali Accademia Italiana di Scienze Forestali, vol. 30, Firenze, Italy.

Bittelli M, Tomei F, Pistocchi A, Flury M, Boll J, Brooks ES, Antolini G (2010). Development and testing of a physically based, three-dimensional model of surface and subsurface hydrology. Advances in Water Resources 33: 106-122. - doi: 10.1016/j.advwatres.2009.10.013

Boitani L, Corsi F, Falcucci A, Marzetti I, Masi M, Montemaggiori A, Ottavini D, Reggiani G, Rondinini C (2002). Rete ecologica nazionale. Un approccio alla conservazione dei vertebrati italiani. Università La Sapienza, Dipartimento di Biologia Animale e dell'Uomo, Roma, Italy. [online] URL: http://www.gisbau.uniroma1.it/REN Borghetti M, Ferrara A (2010). INFC, a different opinion on data availability. Forest@ 7: 1. - doi: 10.3832/efor0613-007

Bossel H (1991). Modelling forest dynamics: moving from description to explanation. Forest Ecology and Management 42: 129-142. - doi: 10.1016/0378-1127(91)90069-8

Bossel H (1994). Modelling and simulation. A.K. Peters Ltd., Wellsley, UK.

Botkin DB, Janak JF, Wallis JR (1972). Some ecological consequences of a computer model of forest growth. Journal of Ecology 60: 849-873. - doi: $10.2307 / 2258570$

Brang P, Courbaud B, Fischer A, Kissling-Näf I, Pettenella D, Schönenberger W, Spörk J, Grimm V (2002). Developing indicators for the sustainable management of mountain forests using a modelling approach. Forest Policy and Economics 4: 113-123. - doi: 10.1016/S1389-9341(02) 00011-4

Brugnoli A, Brugnoli R (2006). La foresta come habitat del Gallo cedrone: ricerca applicata e nuove esperienze di gestione. Forest@ 3: 168182. - doi: 10.3832/efor0358-0030168 Bruner HD, Moser JW (1973). A Markov chain approach to the prediction of diameter distributions in uneven-aged forest stands. Canadian Journal of Forest Research 3: 409-417. - doi: $10.1139 / \times 73-059$

Bugmann H (2001). A review of forest gap models. Climate Change 51: 259-305. - doi: 10. 1023/A:1012525626267

Bugmann H, Palahi M, Bontemps JD, Tome T (2010). Trends in modeling to address forest management and environmental challenges in Europe: introduction. Forest Systems 19: 3-7.

Burkhart HE, Rauscher HM, Johann K (1989). Artificial intelligence and growth models for forest management decisions. In: Proceedings of a meeting at Universitat fur Bodenkultur, Vienna (Austria) Sep. 18-22, 1989. FWS-1-89, School of Forestry and Wildlife Resources, Virginia Polytechnic Institute and State University, Blacksburg, VA, USA.

Camia A (2009). Storia, sviluppi recenti e applicazioni della previsione del pericolo di incendio boschivo in Italia. In: "Atti del Terzo Congresso Nazionale di Selvicoltura per il miglioramento e la conservazione dei boschi italiani" (Ciancio O ed). Vol. 1, AISF, Firenze, pp. 339344. - doi: 10.4129/CNS2008.047

Cantiani MG, Floris A, Tabacchi G (2000). Aspetti produttivi delle peccete altomontane e subalpine della Val di Fiemme. Comunicazioni di ricerca dell'ISAFA, vol. 3, Trento, Italy, pp. 321.

Carpenter S (2002). Ecological futures: building an ecology of the long now. Ecology 83: 20692083. - doi: 10.1890/0012-9658(2002)083[2069: EFBAEO]2.0.CO;2

Castellani C (1982). Tavole stereometriche ed alsometriche costruite per i boschi italiani. Istituto Sperimentale per l'Assestamento Forestale e per l'Alpicoltura, Trento.

Cescatti A, Piutti E (1998). Silvicultural alternatives, competition regime and sensitivity to climate in a European beech forest. Forest Ecology and Management 102(2-3): 213-223. - doi: 10.1016/S0378-1127(97)00163-1

Ciancio O, Nocentini S (2004). Il bosco ceduo. Selvicoltura Assestamento Gestione. Accademia Italiana di Scienze Forestali, Firenze, Italy.

Collalti A, Santini M, Valentini R (2010). Light competition and carbon partitioning-allocation in an improved forest ecosystem model. Geophysical Research, Abstracts EGU2010-12135.

Coops NC, Waring RH, Landsberg JJ (1998). Assessing forest productivity in Australia and New 
Zealand using a physiologically-based model driven with averaged monthly weather data and satellite-derived estimates of canopy photosynthetic capacity. Forest Ecology and Management 104: 113-127. - doi: 10.1016/S0378-1127(97) 00248-X

Corona P, Marziliano PA, Scotti R (2002). Topdown growth modelling: a prototype for poplar plantations in Italy. Forest Ecology and Management 161: 65-73. - doi: 10.1016/S0378-1127(01) 00481-9

Corona P, Scotti R (1998). Forest growth-andyield models: questioning support for sustainable forest management. Journal of Sustainable Forestry 7 (3-4): 131-143. - doi: 10.1300/J091 v07n03 08

Corona P, Scotti R, De Paoli M, Tomaiuolo M (1997). DOUG IT: a growth-and-yield Java applet for Italian Douglas-fir plantations. In: Proceedings of the IUFRO Conference "Modelling growth of fast-grown tree species" (Ortega A, Gezan S eds). Universidad Austral de Chile 5-7 September 1997, pp. 118-126.

Corpo Forestale dello Stato (2010). Dati statistici sugli incendi boschivi in Italia. [online] URL: http://www3.corpoforestale.it/flex/cm/pages/Serv eAttachment.php/L/IT/D/c\%252F9\%252F9 \%252FD.ea01b37fb7975b98cf92/P/BLOB $\% 3 \mathrm{AID} \% 3 \mathrm{D} 1665$

Crookston NL, Rehfeldt GE, Dixon GE, Weiskittel AR (2010). Addressing climate change in the forest vegetation simulator to assess impacts on landscape forest dynamics. Forest Ecology and Management 260: 1198-1211. - doi: 10.1016/j.foreco.2010.07.013

Dale VH, Joyce LA, McNulty S, Neilson RP, Ayres MP, Flannigan MD, Hanson PJ, Irland LC, Lugo AE, Peterson CJ, Simberloff D, Swanson FJ, Stocks BJ, Wotton BM (2001). Climate change and forest disturbances. BioScience 51: 723-734. - doi: 10.1641/0006-3568(2001)051 [0723:CCAFD]2.0.CO;2

Ditzer T, Glauner R, Forster M, Kohler P, Huth A (2000). The process-based stand growth model FORMIX 3-Q applied in a GIS environment for growth and yield analysis in a tropical rain forest. Tree Physiology 20: 367-381. - doi 10.1093/treephys/20.5-6.367

Dixon GE (2003). Essential FVS: a user's guide to the Forest Vegetation Simulator. Internal Report, Forest Management Service Center, USDA Forest Service, Fort Collins, CO, USA.

Dixon R, Meldahl R, Ruark G, Warren W (1990). Process modeling of forest growth responses to environmental stress. Timber Press, Portland, OR, USA.

Dreyfus P, Bonnet FR (1996). CAPSIS (Computer-Aided Projection of Strategies In Silviculture): an interactive simulation and comparison tool for tree and stand growth, silvicultural treatments and timber assortment. In: Proceedings of the Conference on "Connection Between Silviculture and Wood Quality Through Modelling Approaches and Simulation Softwares" (Nepveu G ed). INRA, Nancy, France, pp. 194-202.

Drigo R, Chirici G, Lasserre B, Marchetti M
(2007). Analisi su base geografica della domanda e dell'offerta di combustibili legnosi in Italia. L'Italia Forestale e Montana 5-6: 304-324. Dudek A, Ek AR (1980). A bibliography of worldwide literature on individual tree based forest stand growth models. Staff Paper Series 12, Department of Forest Resources, University of Minnesota, St. Paul, USA.

Eastaugh CS, Pötzelsberger E, Hasenauer H (2011). Assessing the impacts of climate change and nitrogen deposition on Norway spruce (Picea abies L. Karst) growth in Austria with BIOME-BGC. Tree Physiology 31:262-274. doi: 10.1093/treephys/tpr033

Ek A, Burk T, Shifley S (1988). Forest growth modelling and prediction. In: Proceedings of the IUFRO Conference. Minneapolis (USA) August 23-27, 1987. GTR-NC-120, North Central Forest Experiment Station, USDA Forest Service, Chicago, USA.

Fiorese G, Gatto M, Ranci Ortigosa G, De Leo G (2005). Scenari futuri di impatto dei cambiamenti climatici globali tramite l'applicazione di modelli di vocazionalità faunistica a ungulati alpini. In: Atti del XV Congresso Nazionale della Società Italiana di Ecologia (Comoglio C, Comino E, Bona F eds). Torino (Italy) 12-14 settembre 2005. [online] URL: http://www.xvcongresso.societaitalianaecologia.org/articles

Fontes L, Bontemps JD, Bugmann H, Van Oijen M, Gracia C, Kramer K, Lindner M, Rötzer T, Skovsgaard JP (2010). Models for supporting forest management in a changing environment. Forest Systems 2010: 8-29.

Franc A, Gourlet-Fleury S, Picard N (2000). Une introduction à la modélisation des forêts hétérogènes. ENGREF, Nancy, France.

Franklin O, Moltchanova E, Kraxner F, Seidl R, Böttcher H, Rokityiansky D, Obersteiner M (2012). Large-scale forest modeling: deducing stand density from inventory data. International Journal of Forestry Research 2012: 934974 . doi: $10.1155 / 2012 / 934974$

Fries J (1974). Growth models for tree and stand simulation: proceedings of meetings in 1973. Research notes \#30, Dept. of Forest Yield Research, IUFRO Working Party S4.01, Stockholm, Sweden.

Gasparini P, Maltoni ML, Tabacchi G (2000). Un modello a matrice di transizione per i boschi misti pluristratificati di abete rosso, abete bianco e faggio, del Trentino. Vol. 3, Comunicazioni di ricerca ISAFA, Trento, Italy, pp. 23-88.

Godfrey K (1983). Compartmental models and their applications. Academic Press, New York, USA.

Grimm V, Railsback S (2005). Individual-based modeling and ecology. Princeton University Press, Princeton, USA.

Haefner J (2005). Modeling biological systems: principles and applications. Springer, New York, USA

Hanewinkel M, Peltola H, Soares P, Gonzales-Olabarria JR (2010). Recent approaches to model the risk of storm and fire to European forests and their integration into simulation and decision support tools. Forest Systems 19: 30-47. Hasenauer H (1994). A single tree simulator for uneven-aged mixed species stands. In: "Mixed Stands: Research Plots, Measurements and Results, Models" (Pinto da Costa ME, Preuhsler T eds). Instituto superior de Agronomia, Universidad Técnica de Lisboa, Portugal, pp. 255-270.

Hasenauer H (2006). Sustainable forest management: growth models for Europe. Springer, Berlin, Germany. - doi: 10.1007/3-540-31304-4

Hasenauer H, Mäkelä A (2005). Modeling forest production: scientific tools, data needs and sources, validation and application. In: Proceedings of an International Conference. Vienna (Austria) April 19-21, 2004. Department of Forest and Soil Sciences, University of Natural Resources and Applied Life Sciences, Vienna, Austria.

He (2008). Forest landscape models: Definitions, characterization, and classification. Forest Ecology and Management 254: 484-498. - doi: 10.1016/j.foreco.2007.08.022

INFC (2005). Inventario Nazionale delle Foreste e dei Serbatoi Forestali di Carbonio. Ministero delle Politiche Agricole Alimentari e Forestali, Ispettorato Generale - Corpo Forestale dello Stato, Roma, Italy. CRA - Unità di ricerca per il Monitoraggio e la Pianificazione forestale, Roma, Italy.

ISTAT (2000). Censimento Generale dell'Agricoltura 2000. Web Site. [online] URL: http://censagr.istat.it/dati.htm

ISTAT (2006). Statistiche dell'Agricoltura. Collana annuari n. 49, IRoma, Italy.

Kimmins J (2008). From science to stewardship: harnessing forest ecology in the service of society. Forest Ecology and Management 256: 1625-1635. - doi: 10.1016/j.foreco.2008.02.057 Kimmins JP (1993). Scientific foundations for the simulation of ecosystem function and management in FORCYTE-11. Northwest region. Information Report NOR-X-328, Forestry Canada, Edmonton, Canada.

Landsberg JJ, Waring RH (1997). A generalised model of forest productivity using simplified concepts of radiation-use efficiency, carbon balance and partitioning. Forest Ecology and Management 95:209-228. - doi: 10.1016/S03781127(97)00026-1

Laneve G, Cadau EG (2007). Quality assessment of the fire hazard forecast based on a fire potential index for the Mediterranean area by using a MSG/SEVIRI based fire detection system. In: Proceedings of the "IEEE International Geoscience and Remote Sensing Symposium”. Barcelona (Spain), 23-28 July 2007, pp. 2447-2450.

Leemans R, Prentice IC (1989). FORSKA, a general forest succession model. Institute of Ecological Botany, Uppsala, Sweden.

LeMay V, Marshall P (2003). Foreword. Canadian Journal of Forest Research 33: vii-viii.

Liski J, Perruchoud P, Karjalainen K (2002). Increasing carbon stocks in the forest soils of Western Europe. Forest Ecology and Management 169: 159-175. - doi: 10.1016/S0378-1127 (02) 00306-7 
Makela A, Landsberg J, Ek AR, Burk TE, Ter-Mikaelian M, Agren GI, Oliver CD, Puttonen P. (2010). Process-based models for forest ecosystem management: current state of the art and challenges for practical implementation. Tree Physiology 20: 289-298. - doi: 10.1093/treephys/20.5-6.289

Marletto V, Zinoni F, Filippi N, Angelelli AM Laruccia N, Lega P, Tonelli T (1993). CRITERIA: an integrated geo-graphical system for soil water monitoring. In: Proceedings of the "IX Symposium on Pesticide Chemistry, Mobility and Degradation of Xenobiotics" (Del Re AAM, Capri E, Evans SP, Natali P, Trevisan MP eds). Piacenza (Italy) 12-13 october 1993, pp. 695 706.

Marziliano PA (2009). Resampling procedures to validate dendro-auxometric regression models. Forest@6: 100-106. - doi: 10.3832/efor0565006

Maselli F, Moriondo M, Chiesi M, Chirici G, Puletti N, Barbati A, Corona P (2009). Evaluating the Effects of Environmental Changes on the Gross Primary Production of Italian Forests. Remote Sensing 1 (4): 1108-1124. - doi: 10.3390/ rs 1041108

McMurtrie RE, Gholz HL, Linder S, Gower ST (1994). Climatic factors controlling the productivity of pine stands: a model-based analysis. Ecological Bulletin 43: 173-188. [online] URL: http://www.jstor.org/stable/20113140

MCPFE (2000). General declarations and resolutions adopted at the Ministerial conference on the protection of forests in Europe. Strasbourg 1990, Helsinki 1993, Lisbon 1998. Liaison Unit, Ministerial conference on the protection of forests in Europe, Vienna, Austria.

Michener WK (2006). Meta-information concepts for ecological data management. Ecological Informatics 1: 3-7. - doi: 10.1016/j.ecoinf.2005. 08.004

Minunno F, Xenakis G, Percks M P, Mencuccini $M$ (2010). Calibration and validation of a simplified process-based model for the prediction of the carbon balance of Scottish Sitka spruce (Picea sitchensis) plantations. Canadian Journal of Forest Research 40: 2411-2426. - doi: 10.1139/X10-181

Mladenoff D, Baker W (1999). Spatial modeling of forest landscape change: approaches and applications. Cambridge University Press, Cambridge, UK.

Monserud RA (2003). Evaluating forest models in a sustainable forest management context. Forest Biometry, Modelling and Information Sciences 1: 35-47.

Morani A (2009). Optimizing tree planting in New York city. Tesi di laurea di secondo livello, Università della Tuscia, Facoltà di Agraria, Viterbo, Italy.

Munro D (1974). Forest growth models: a prognosis. In: Proceedings of "Growth models for tree and stand simulation" (Fries J eds). Royal College of Forestry, Stockholm, Sweden, pp. 721.

Nightingale JM, Hill MJ, Phinn SR, Davies ID,
Held AA, Erskine PD (2008). Use of 3-PG and 3-PGS to simulate forest growth dynamics of Australian tropical rainforests: I. Parameterisation and calibration for old-growth, regenerating and plantation forests. Forest Ecology and Management 254: 107-121. - doi: 10.1016/j.foreco. 2007.03 .041

Nolé A, Law BE, Magnani F, Matteucci G, Ripullone F, Borghetti M (2009). Application of the 3PGs model to assess carbon accumulation in forest ecosystems at a regional level. Canadian Journal of Forest Research 3 (9): 1647-1661. doi: 10.1139/X09-077

O'Neill RV, De Angelis DL, Waide JB, Allen TFH (1986). Hierarchical concept of ecosystems. Monographs in Population Biology 23: 1-272.

Orazio C (2009). FORMODEL: Register of model for forests. Web Site. [online] URL: http://w3.pierroton.inra.fr/IEFC/bdd/models/mod eles liste.php

Pacala SW, Canham CD, Silander J (1993). Forest models defined by field measurements: I. The design of a northeastern forest simulator. Canadian Journal of Forest Research 23: 1980-1988. doi: 10.1139/x93-249

Palahí M (2008). Forest models for research and decision support in sustainable forest management. WG1: Summary of the information from the country templates. [online] URL: http://www.isa.utl.pt/def/fp0603forestmodels/PD F/Synthesis-WG1-Vienna-2008.pdf

Peng C (2000). Growth and yield models for uneven-aged stands: past, present and future. Forest Ecology and Management 132: 259-279. - doi: 10.1016/S0378-1127(99)00229-7

Pickett STA, Kolasa J (1989). Structure of theory in vegetation science. Plant Ecology 83: 7-15. doi: 10.1007/BF00031677

Porté A, Bartelink HH (2002). Modelling mixed forest growth: a review of models for forest management. Ecological Modelling 150: 141-188. doi: 10.1016/S0304-3800(01)00476-8

Potter CS, Kloster S, Brooks V (1998). Interannual variability in terrestrial net primary production: exploration of trends and controls on regiona scales. Ecosystems 2: 36-48. - doi: $10.1007 /$ s 100219900056

Pretzsch H (1999). Modelling growth in pure and mixed stands: a historical overview. In: "Management of mixed-species forest: silviculture and economics" (Olsthoorn AFM, Bartelink HH, Gardiner JJ, Pretzsch H, Hekhuis HJ, Franc A, Wall S eds). Instituut voor Bos- en Natuuronderzoek DLO, Wageningen, The Netherlands, pp. 102-107.

Pretzsch H (2009). Forest dynamics, growth, and yield: from measurement to model. Springer, Berlin, Germany. - doi: 10.1007/978-3-54088307-4

Pretzsch H, Biber P, Dursky J, Gadow K, Hasenauer H, Kändler G, Kenk G, Kublin E, Nagel J, Pukkala T, Skovsgaard J, Sodtke R, Sterba $H$ (2006). Standardizing and categorizing tree growth models. In: "Sustainable Forest Management: growth models for Europe" (Hasenauer H ed). Springer, Berlin, Germany, pp. 39-57. - doi:
10.1007/3-540-31304-4_3

Pretzsch H, Grote R, Reineking B, Rotzer T, Seifert S (2008). Models for forest ecosystem management: a European perspective. Annals of Botany 101: 1065-1087. - doi: 10.1093/aob/ mem 246

Pretzsch H, Kahn M (1996). Wuchsmodelle für die Unterstützung der Wirtschaftsplanung im Forstbetrieb. Allgemeine Forst Zeitschrift Der Wald 25: 1414-1419.

Price DT, Zimmermann NE, van der Meer PJ, Lexer MJ, Leadley P, Jorritsma ITM, Schaber H, Clark DF, Lasch P, McNulty S, Wu JG, Smith B (2001). Regeneration in gap models: priority issues for studying forest responses to climate change. Climate Change 51:475-508. - doi: 10.1023/A:1012579107129

Rennolls K, Ibrahim M, Smith P (2001). A forest model archive. In: Proceedings of IUFRO 4.11 Conference on "Forest Biometry, Modelling and Information Sciences" (Rennols K eds). University of Greenwich (UK) June 2001, pp. 17.

Rennols K (2001). Forest biometry, modelling and information science. In: Proceedings of a IUFRO 4.11 conference. University of Greenwich (UK) June 2001. [online] URL: http://cms1.gre.ac.uk/ conferences/iufro/proceedings/

Rigon R, Bertoldi G, Over TM (2006). GEOtop: a distributed hydrological model with coupled water and energy budgets. Journal of Hydrometeorology 7: 371-388. - doi: 10.1175/JHM497.1

Robinson AP, Ek AR (2000). The consequences of hierarchy for modeling in forest ecosystems. Canadian Journal of Forest Research 30: 18371846. - doi: 10.1139/x00-117

Running SW, Nemani RR, Heinsch FA, Zhao MS, Reeves M, Hashimoto H (2004). A continuous satellite-derived measure of global terrestrial primary production. Bioscience 54:547-560. doi: 10.1641/0006-3568(2004)054[0547:ACSMOG]2.0.CO;2

Scarfò F, Mercurio R (2009). Il calcolo dei crediti di carbonio: il modello CO2FIX v. 3.1 applicato ad una faggeta sotto Forest Management nel sud Italia. Forest@6: 215-228. - doi: 10.3832/ efor0587-006

Scheller RM, Domingo JB, Sturtevant BR, Williams JS, Rudy A, Gustafson EJ, Mladenoff DJ (2007). Design, development, and application of LANDIS-II, a spatial landscape simulation model with flexible temporal and spatial resolution. Ecological Modelling 201: 409-419. - doi: 10.1016/j.ecolmodel.2006.10.009

Scotti R, Corona P, La Marca O, Marziliano PA, Tarchiani N, Tomaiuolo M (1995). Growth model for italian douglas-fir plantations. In: "Recent advances in forest mensuration and growth and yield research". Proceedings from 3 sessions of Subject Group S4.01 "Mensuration, Growth and Yield", 20 ${ }^{\text {th }}$ World Congress of IUFRO (Skovsgaard JP, Burkhart HE eds). Tampere (Finland) 6-12 August 1995. Finnish Forest and Landscape Research Institute, Tampere, Finland, pp. 175193.

Seidl R, Fernandes PM, Fonseca TF, Gillet F, Jönsson AM, Merganičová K, Netherer S, Arpaci 
A, Bontemps Bugmann H, González-Olabarria JR, Lasch P, Meredieu C, Moreira F, Schelhaas MJ, Mohren F (2011). Modelling natural disturbances in forest ecosystems: a review. Ecological Modelling 222: 903-924. - doi: 10.1016/j.ecolmodel.2010.09.040

Seidl R, Rammer W, Scheller RM, Spies TA (2012). An individual-based process model to simulate landscape-scale forest ecosystem dynamics. Ecological Modelling 231: 87-100. doi: 10.1016/j.ecolmodel.2012.02.015

Shugart HH (1984). A theory of forest dynamics the ecological implications of forest succession models. Springer, New York, USA. - doi 10.1007/978-1-4419-8748-8

Shugart HH, Michaels PJ, Smith TM, Weinstein DA, Rastetter EB (1988). Simulation Models of Forest Succession. In: "Scales and global change: spatial and temporal variability in biospheric and geospheric processes" (Rosswall T, Woodmansee RG, Risser PG eds). John Wiley and Sons, Chichester, USA, pp. 125-151.

Sims AW (2009). Takseermudelite ja andmestike infosüsteem puistu kasvukäigu modelleerimiseks. Ph.D. thesis, Estonian University of life Sciences, Institute of Forestry and Rural Engineering, pp. 148.

Solomon AM, Shugart HH (1993). Vegetation dynamics and global change. Springer, New York, USA. - doi: 10.1007/978-1-4615-2816-6

Stage AR (1973). Prognosis model for stand development. Research Paper INT-137, Intermountain Forest and Range Experiment Station, USDA Forest Service, Ogden, UT, USA.

Taylor AR, Chen HYH, VanDamme L (2009). A review of forest succession models and their suitability for forest management planning. Forest Science 55: 23-36

Thornley J, Johnson I (2002). Plant and crop mo- delling: a mathematical approach to plant and crop physiology. Blackburn Press, Caldwell, NJ, USA.

Vacchiano G, Motta R, Long JN, Shaw JD (2008). A density management diagram for Scots pine (Pinus sylvestris L): a tool for assessing the forest's protective effect. Forest Ecology and Management 255: 2542-2554. - doi: 10.1016/j.foreco.2008.01.015

Valentini R (2003). Fluxes of carbon, water and energy of European forests. Springer, Berlin, Germany.

Van Oijen M, Rougier J, Smith R (2005). Bayesian calibration of process-based forest models: bridging the gap between models and data. Tree Physiology 25 (7): 915-927. - doi: 10.1093/treephys/25.7.915

Vanclay J (1994). Modelling forest growth and yield: applications to mixed tropical forests. CAB International, Wallingford, USA.

Vanclay JK, Skovsgaard JP (1997). Evaluating forest growth models. Ecological Modelling 98: 1-12. - doi: 10.1016/S0304-3800(96)01932-1

Ventura F, Marletto V, Zinoni F (2001). Un metodo per il calcolo dell'indice meteorologico del rischio di incendio forestale. Sherwood 68: 1318.

Veroustraete F, Sabbe H, Eerens H (2002). Estimation of carbon mass fluxes over Europe using the C-Fix model and Euroflux data. Remote Sensing of Environment 83:376-399. - doi: 10.1016/S0034-4257(02)00043-3

Virgilietti P, Buongiorno J (1997). Modeling forest growth with management data: a matrix approach for the Italian Alps. Silva Fennica 31: 27-42.

Voinov A, Jakeman A, Rizzoli A, Chen S (2008). Environmental modelling, software and decision support: In: "State of the Art and New Perspec- tive”. Elsevier Science, Oxford, UK.

Von Gadow K, Hui G (2001). Modelling forest development. Springer, New York, USA.

Waring RH, Running SW (1998). Forest ecosystems - analysis at multiple scales. Academic Press, San Diego, USA. - doi: 10.1016/B978012370605-8.50005-0

Weisberg PJ, Bonavia F, Bugmann H (2005). Modeling the interacting effects of browsing and shading on mountain forest tree regeneration (Picea abies). Ecological Modelling 185: 213 230. - doi: 10.1016/j.ecolmodel.2004.12.004

Wensel LC, Biging GS (1990). Forest simulation systems. In: Proceedings of the IUFRO conference, Oakland (CA, USA) November 2-5, 1988. Bulletin no. 1927, Division of Agriculture and Natural Resources, University of California, Oakland, CA, USA.

Wiens JA (1989). Spatial scaling in ecology. Functional ecology 3: 385-397. - doi: 10.2307/ 2389612

Xenakis G, Ray D, Mencuccini M (2008). Sensitivity and uncertainty analysis from a coupled 3PG and soil organic matter decomposition model. Ecological Modelling 219: 1-16. - doi: 10.1016/j.ecolmodel.2008.07.020

Zaehle S, Dalmonech D (2011). Carbon-nitrogen interactions on land at global scales: current understanding in modelling climate biosphere feedbacks. Current Opinion in Environmental Sustainability 3: 311-210. - doi: 10.1016/j.cosust. 2011.08 .008

\section{Notes}

1. European Cooperation in Science and Technology (http://www.cost.eu).

2. The workshop program is available at the Working group website (http://sisef.org/gdl/ modellistica/), in Italian language. 